\title{
A critical engagement? Analysing same-sex marriage discourses in To Have and to Hold: The Making of Same-Sex Marriage in South Africa (2008) - A queer perspective
}

\author{
Tracey L. McCormick \\ University of Johannesburg, South Africa \\ Email: traceym@uj.ac.za
}

\begin{abstract}
The legalisation of same-sex marriage in South Africa in November 2006 made the country the exemplar for gay and lesbian rights in Africa. The advocacy of, struggle for, and finally winning the right to marry was a euphoric victory for numerous gay and lesbian people. The various steps that had to be negotiated in order to pass the Civil Union Act are documented in To Have and to Hold: The Making of Same-Sex Marriage in South Africa (2008, hereafter To Have and to Hold). The blurb at the back of To Have and to Hold describes the book as "invaluable for understanding [the same-sex marriage] journey and its legal, social, cultural and religious ramifications". The editors of the volume, Judge, Manion and de Waal, add that the various stakeholders that supported same-sex marriage "adequately interrogated the role and function of marriage" (Judge et al. 2008: 12). In this article, I put this claim to the test by interrogating the legal, social, cultural and religious reasons put forward in favour of same-sex marriage in To Have and to Hold. From a queer point of view, same-sex marriage is problematic because it ignores the regulatory power of the state, the fact that marriage is a public tradition, the argument that the supposed "respectability" bestowed by marriage is a farce, and the contention that legal benefits should be given to people regardless of their marital status. I use queer linguistic tools to deconstruct the claim by the editors that the text represents a "critical engagement" with same-sex marriage (Judge et al. 2008: 1). I conclude the article by showing how, rather than opening a space for the "recognition of diverse sexualities and relationship forms" (Judge et al. 2008: 12), the Civil Union Act is limited to those people who self-identify as gay or lesbian.
\end{abstract}

Keywords: queer, same-sex marriage, South Africa, discourse

\section{Introduction}

Transgender political activists and academics Spade and Willse (2013: n.p.) argue that the "existence of legal marriage is a form of coercive regulation in which achieving or not achieving marital status is linked to accessing vital life resources like health care and paths to legalized immigration". Given this critical view of same-sex marriage, it is unclear exactly how same- 
sex marriage has come to top the agenda of many gay and lesbian movements worldwide since the late 1990s (Warner 1999). Queer gender theorist Judith Halberstam goes even further by suggesting that "marriage is an agenda forced upon LGBT groups by the widespread opposition to gay marriage, and while some gays and lesbians choose to marry, it's not a cause that lies at the heart of queer community" (Halberstam 2012: 114). However, what was once a whimsical wish has become a very significant human rights issue. As Yarbrough (2006: 497) puts it, samesex marriage has progressed into the "seemingly inevitable civil rights issue of our time". In the South African context, this right is a reality that often results in South Africa being perceived as "the most egalitarian society in the world" (Stacey and Meadow 2009: 171). Therefore, what would the purpose be of a queer critique of same-sex marriage in the South African context when, as Warner (1999: 83) argues, "the ship has sailed"?

My purpose in this article is threefold. Firstly, the majority of the academic writings on same-sex marriage in South Africa originate from the legal field. I, however, would like to offer a contribution from a different point of view, one that originates from queer studies. Secondly, opposition to same-sex marriage prior to the passing of the Civil Union Act in 2006 was homophobic in nature. Reddy (2009: 358) correctly laments that, "sadly, the dominant opposition to the same-sex marriage issue is usually framed in ways that account for difference as a type of deviance". In contrast, I critique same-sex marriage in this article from an anti-homophobic perspective. Finally, I would like to contribute to the debate on how to develop strategies to resist discrimination and violence against people who are queer or "other".

I begin the article by providing an overview of the literature on same-sex marriage in South Africa in which I show not only the legal bias in the output, but also the lack of dissension and radical critique of same-sex marriage. This is followed by an exposition of the queer position on same-sex marriage in order to highlight the tensions involved in the opposition to same-sex marriage by non-conforming activists and academics. I then orientate the reader towards the intensity of the same-sex-marriage debate in countries in which same-sex marriage has yet to be legalised. In the ensuing section, I explain the queer lenses that inform the analysis of the edited collection To Have and to Hold (2008).

To Have and to Hold is a collection of 40 chapters (10 scholarly and 30 personal) written by "an impressive selection of academics, attorneys, researchers, activists and others" who "critically examine the legislative and advocacy process to marriage" and question "whether the attainment of the right to marry and the Civil Union Act itself should warrant celebration or circumspection" (quoted from the blurb at back of book). Included is a practical guide to the Civil Union Act, which the editors of the book encourage couples to read if they are "eager to tie the knot" (Judge et al. 2008: 7). The editors of To Have and to Hold make it very clear that the aim of the book is a celebration of the right of gay and lesbian people in South Africa to marry, a "critical engagement" with marriage and a resource for "human-rights advocacy" (Judge et al. 2008: 1). My choice of To Have and to Hold as the object of this investigation is motivated by the position of this publication as the major contributor to the same-sex debate in the South African context. I conclude this article by arguing that, despite the lofty ideals associated with the Civil Union Act, which would open a space for the "recognition of diverse sexualities and relationship forms" (Judge et al. 2008: 12), in fact, quite the opposite has occurred. 


\section{An overview of the literature on same-sex marriage in South Africa}

There is very little scholarly literature on same-sex marriage in South Africa. As Thoreson (2008: 679) notes, "South Africa's gay, lesbian and bisexual (GLB) movements [and] legal victories especially on same-sex marriage [are] little-discussed in the scholarly literature". Research by Robinson and Swanepoel (2004), Williams (2004) and Reddy (2006), prior to the passing of the Civil Union Act in 2006, documented the complexities and resistances encountered in trying to pass legislation that legalised same-sex marriage. Although these writers did acknowledge the problematic nature of marriage, it is argued by all three that such problems need to be overlooked for "reasons of principle" (Williams 2004: 32). Not allowing gay and lesbian people to marry "violate[s] the rights of lesbians and gay men to equality, dignity and privacy" (Reddy 2006: 152). Writing just after the passing of the Civil Union Act, legal academic Beth Goldblatt (2006: 261) concurs with the above writers but expresses concern for domestic partners whose rights "lag behind, often to the detriment of women in these relationships". De Vos and Barnard (2007: 825) also articulate their "discomfort" with the exclusionary nature of the Civil Union Act whilst at the same time "celebrating the enormous progressive step South Africa has taken" as the "marginalized same-sex couple now has a new means of accessing the mainstream, where they choose to do so".

In 2007, the South African Journal on Human Rights published a special issue on the theme of "Sexuality and the Law", which contains six articles dedicated to the subject. The sexuality under discussion was homosexuality, and all of the articles dealt with the significance of the passing of the Civil Union Act in 2006. Goldblatt and Pantazis; Robson; De Vos; Bilchitz and Judge; Barnard, and Picarra (2007) investigate the legal nuances of, as well as the problems with, the Civil Union Act but, ultimately, all agree that legalising same-sex marriage is about the equal treatment of heterosexual and homosexual people. Bilchitz and Judge (2007: 466) argue that the Civil Union Act reforms family law. Not only does it ensure that gay and lesbian married relationships are recognised, but the Civil Union Act also "decentres marriage [...] allowing a diversity of relationships to be recognised in our law"1. Picarra (2007: 569) too identifies the Civil Union Act as being the first link in a chain of change regarding the more troublesome aspects of family law in South Africa when she writes that "the possibility may well now exist for unwed heterosexual and same-sex domestic relationships to be brought under the protection of the law". De Vos (2007: 432) notes that challenges to homophobic laws post1994 have been based on "elite-based legal battle[s]" that "failed to build a sustainable vibrant grassroots movement"2. This critical point notwithstanding, he argues that same-sex marriage reform has opened a "symbolic space" that will "begin to allow [...] for true emancipation of gay men and lesbians" (De Vos 2007: 432).

The most substantive engagement with same-sex marriage in South Africa, beyond the legal bias of the years 2004 to 2007, has been made by Bonthuys (2008a) writing in the international journal Sexualities (an abridged version of this article appears in To Have and to Hold) ${ }^{3}$. The

\footnotetext{
${ }^{1}$ The validity of such an assertion is scrutinised in my data analysis section.

${ }^{2}$ Cf. Cock (2003) and Oswin (2007).

${ }^{3}$ The only critique of same-sex marriage in To Have and to Hold, besides that of Bonthuys, is from lesbian feminist writers. This point of view is represented by Hames (2008: 263) who condemns same-sex marriage as a compromise for lesbians. She argues that marriage reinforces "heterosexist and patriarchal social norms" and, consequently, will force lesbians to adopt either a butch or a femme gender role. This imitation of heterosexuality would be the result of the pressure to "fit in" (Hames 2008: 263). Hames (2008) believes that lesbians have
} 
author argues that the Civil Union Act is restricted to gay and lesbian people who are "urban, middle-class people who have the social and economic wherewithal to flout the norms of their families and their religious and cultural communities" (Bonthuys 2008a: 732). The basis of her critique is that, when formulating the Civil Union Act, legislators did not draw from customary law, which has a history of tolerance of a wide array of sexual practices and has "proved more malleable and more responsive to same-sex relationships" compared to civil law (Bonthuys 2008a: 735). Bonthuys makes it clear that, in presenting this critique of the Civil Union Act, she is not saying that customary law is better than civil law since both are "deeply rooted in patriarchy" (2008a: 735). She suggests that the Civil Union Act should have included those "African people who are involved in same-sex relationships that do not fit this profile" (Bonthuys 2008a: 734) such as those who are involved in heterosexual marriages and engage in same-sex relations. The focus of Bonthuys' criticism is not same-sex marriage per se, but is rather directed towards the drafters of the Civil Union Act who ignored "customary examples to imagine richer concepts and more sophisticated forms of legalization", which resulted in the Civil Union Act being an "impoverished and disappointing" piece of legislation (Bonthuys 2008a: 736). Bonthuys' expansion of specifically African queer sexualities beyond the rigid boundaries of the middle-class heterosexual economy is a critique that is a welcome addition to the otherwise legally orientated, staid and conformist approaches to same-sex marriage in South Africa. However, in the final analysis she differs very little from all other commentators when she concedes that her critique of same-sex marriage does not imply "that same-sex marriage should not have been legalized" (Bonthuys 2008a: 735).

Reddy (2009: 356) acknowledges that the same-sex marriage debate is "contentious, politically charged and is underpinned by diverse and complicated considerations". However, like De Vos and Barnard (2007), he states that such complications should not be overshadowed by the fact that "the right to marry represents a human and civil rights matter that is connected to politics, culture, law, identity and individual choice and freedom" (Reddy 2009: 354). Reddy believes that same-sex marriage has the potential to transform gay and lesbian politics, and contends that the "legal right to marriage is one of the final hurdles in overcoming discrimination against gays and lesbians" (Reddy 2009: 346). For the late sexual and lesbian rights activist and scholar Mikki Van Zyl (2011), the fact that same-sex marriage is legal is a result of the lobbying by white, middle-class, gay males. This is problematic for her as the privilege of race, class and status, she argues, "effectively erased from the equality clause [...] queers, female-headed households, unmarried mothers, pregnant teenagers, and people living with HIV and AIDS" (Van Zyl 2011: 351). Similarly to Bonthuys (2008a), Van Zyl argues that when drafting the Civil Union Act there was little consideration of those kinship relations and same-sex practices that existed in pre-colonial Africa that created spaces for alternative desires. As Van Zyl's critique can be considered a critique from "within" the same-sex marriage debate, writing that same-sex marriage has the "potential to effect social transformation of contemporary kinship relationships, and challenge the assumed heteronormativity of everyday life" (Van Zyl 2011:

developed relationship types that "somehow transcend heterosexist ones". Therefore, lesbians could have transformed marriage by not adopting gendered butch or femme roles; instead, there is now pressure for "gay couples to indulge in roles that mimic such norms" (Hames 2008: 263). Hames' lesbian feminist argument that butch-femme role-playing contributes to patriarchal domination is based on the belief that such role-playing mimics the unequal gender roles of men and women. In contrast, Butler (2004) argues that butch-femme roleplaying is not a mere mimicking of gender inequalities, but shows the very instability and masquerading potential of gender in much the same way as drag does. 
354) would be in keeping with her belief that same-sex marriage is ultimately beneficial for gay and lesbian people.

Judge (2014) is concerned with the impact that same-sex marriage has had on masculine and feminine subjectivities. Similar to the research presented above, she is concerned with the contradiction between the promise of legislation and the continued "discrimination and exclusion" of sexual and gendered "others" (Judge 2014: 66). Drawing from Butler (1990) and Dworkin (2006), Judge outlines the radical feminist critique of normativity and marriage. However, she finds "problems" (Judge 2014: 68) with these positions because, just by marrying, same-sex couples pose a threat to "heterosexual domination" and perform "destabilising resistance" to the heteronormative logic of sex and gender (Judge 2014: 69). Finally, in her view, marriage between same-sex couples has "effectively named $[\ldots]$ the love that dare not speak its name" (Judge 2014: 69, original emphasis).

The review of the literature on same-sex marriage in South Africa above highlights that, of the 11 articles published between 2004 and 2007, only Reddy's (2006) article, although legal in its orientation, was published in an anthology and not in a law journal. There is also consensus in all the articles on the progressive nature of same-sex marriage despite the many problems associated with not only marriage per se, but also with the exclusionary nature of the Civil Union Act. The four articles published by Bonthuys, Reddy, Van Zyl and Judge respectively, are substantive critiques of the lack of acknowledgement of common law, indigenous knowledge systems and identity flexibility in the Civil Union Act. However, their critique stops short of being queerly disruptive because they resolve the problems associated with same-sex marriage by arguing that it is either a legal right (Bonthuys 2008a), a way to end discrimination (Reddy 2009), a means of transforming society (Van Zyl 2011) or a transgressive act in itself (Judge 2014). This article contributes to the gap in the literature on same-sex marriage in South Africa by providing a point of view not limited to the law, and by providing a perspective that does not resolve the normativity of marriage in favour of principle, choice, transformation or as a way to end discrimination.

\section{The queer position on same-sex marriage}

The arguments in favour of same-sex marriage can be classified according to four broad themes: choice, love, respectability and benefits (the origination of these arguments I explain in the next section). These arguments have been critiqued by radical, queer and anti-homophobic theorists for ignoring the powerful institutional norms that regulate sexuality (cf. Warner 1999, Butler 2002 and Halberstam 2012) ${ }^{4}$. As Brandzel (2005: 172) notes, the shorter list of such theorists compared to the long list of writers in favour of same-sex marriage (of which the latter is discussed in the next section) highlights the fact that "mainstream discussions of same-sex marriage often elide queer theorists' critiques both of same-sex marriage and of appeals to the state". For example, Butler (2002: 16) argues that gay and lesbian people being sanctioned by the state by means of marriage could lead to "the intensification of normalization". What will happen, she asks, to the "community of the nonmarried, the single, the divorced, the uninterested, the nonmonogamous" when same-sex marriage becomes a reality (Butler 2002: 21)? She also argues that asking the state for the right to marry transforms a "collective delegitimation into a selective one" that is nearly "impossible to reconcile with a radically democratic, sexually progressive movement" (Butler 2002: 27). Spade

\footnotetext{
${ }^{4}$ See also Saalfield (1993), Ettelbrick (1997), Vasquez (1999), Walters (2001), Brandzel (2005), Willse and Spade (2005), Polikoff (2008) and Spade and Willse (2013).
} 
and Willse (2013: n.p.) argue that same-sex marriage advocacy by the "radically democratic, sexually progressive [gay and lesbian] movement in the US [has made] being anti-homophobic synonymous with being pro-marriage". They argue further that such same-sex marriage advocacy has "drowned out centuries of critical thinking and activism against the racialized, colonial, and patriarchal processes of state regulation of family and gender through marriage" (Spade and Willse 2013: n.p.). Spade and Willse (2013: n.p.) make it clear that their critique of same-sex marriage is not anti-assimilationist because this point of view omits the "racial [...] economic justice and decolonial analysis".

Warner's (1999) critique of the choice, love, respectability and benefits arguments in favour of same-sex marriage in the United States (US) context is described as being the "most extensive" (Yep, Lovaas and Elia 2003: 53). For Warner, the choice argument in favour of same-sex marriage would mean that marriage is a private decision that negates the advantageous association with legitimacy which makes people want to get married in the first place. The choice argument would, additionally, only be valid if marriage could be made sense of without allusion to the state. For Warner, this argument "dazzles by its simplicity" (1999: 99) and such simplicity is central to the power of the argument because it makes people forget the ethical critique of marriage in queer politics ${ }^{5}$.

According to Warner (1999), the love argument in favour of same-sex marriage ignores the fact that marriage is a public tradition, the significance and effects of which often extend beyond the love expressed by the two individuals who are getting married. In the love argument, the love evident in same-sex marriages will transform the institution and "push it to be something more radically egalitarian" (Warner 1999: 127). That same-sex marriage will make gay and lesbian people respectable by normalising queer behaviour is unlikely because gay and lesbian people are just as likely to "divorce, cheat, and abuse each other as anyone else" (Warner 1999: 114). Finally, Warner argues that social and legal benefits should be given to people regardless of their marital status, and contends that marriage provides a "short cut" (2008: 121) to obtaining these benefits.

In this article, I draw from these radical critiques of same-sex marriage by Warner (1999), Butler (2002), and Spade and Willse (2013) in order to dissect the presentation of same-sex marriage in To Have and to Hold which resolves any problem associated with marriage in favour of choices, rights and principles.

\section{The same-sex marriage debate from countries where same-sex marriage has yet to be legalised}

Yep et al. (2003: 61) declare that "[t]he issue of same-sex marriage is hotly contested from a variety of perspectives", and same-sex marriage tops the agenda of many gay and lesbian

\footnotetext{
${ }^{5}$ Warner (1999) provides numerous reasons why, historically, the gay and lesbian movement in the US resisted making same-sex marriage central to their political agenda. These reasons include the refusal to make heterosexual norms the measure for queer life, resistance to selective state legitimation of some sexual relations and not others and, most importantly, the awareness that marriage rewards those who comply with it and punishes or makes outcasts of those who do not, such as "adulterers, prostitutes, divorcees, the promiscuous, single people, unwed parents, those below the age of consent" (Warner 1999: 89). Since the 1990s, Warner argues, gay and lesbian activists have not indicated how their desire for same-sex marriage is consistent with the rejection of heterosexual norms. Rather, a case has been made that endorsing same-sex marriage means discarding older types of activism and issues of "antiquated liberationism" (Warner 1999: 90).
} 
movements across the world (e.g. Finland, Colombia, Israel, Mexico, etc.). Although each country has a unique approach and strategy, there are many similarities in the arguments in favour of same-sex marriage ${ }^{6}$.

Kaplan (1997: 206) accurately summarises the most important arguments in favour of samesex marriage: true equality for gay and lesbian people means the legal recognition of their relationships - in other words, the right to marry - so that gay people can be part of "human flourishing on equal terms with straight citizens" in order to achieve "human happiness". That gay people are now able to make such a demand is based on, first, the "political overcoming of the closet" (Kaplan 1997: 202), and second, the shift in the priorities of the gay and lesbian rights movement from the "defensive fight for survival" (Kaplan 1997: 206) to the fight for the legal recognition of relationships. Kaplan (1997: 204) argues that

shifting ground from sexual freedom to the recognition of lesbian and gay partnerships and families asserts a commonality with the professed aspirations of the heterosexual majority and undercuts the construction of queers as sexual subversives.

According to Kaplan (1997), marriage is the only institution that joins people together and obliges the state to provide specific benefits. In addition to state-sanctioned benefits, there are also numerous financial, material and symbolic benefits offered to spouses including employee benefits, access to hospital rooms and nursing homes, participation in life and death decisions, and the right to adopt a child. Ultimately, same-sex marriage is about the legitimation of gay and lesbian people in the eyes of the community, families and "even themselves" (Kaplan 1997: 205). That marriage is a "troubled institution" means that the traditional notion of the nuclear family is "already a fiction" (Kaplan 1997: 221), and Kaplan (1997: 222) claims that same-sex marriage has the potential to challenge such conservativeness and "transform available possibilities".

Kaplan's (1997) arguments in favour of same-sex marriage - the choice to marry, love or "human happiness" (1997: 206), respectability, and legal and social benefits - are echoed by numerous writers ${ }^{7}$. The choice, love, respectability and benefits arguments in favour of same-sex marriage have definitely influenced South African writers, and there are many similarities in the arguments, from "choice" to the most favoured political strategy, litigation". Thoreson (2008: 679) makes this very clear when stating that "the GLB movement [in South Africa] has succeeded because stable political alignments allow it to concentrate on lobbying and litigation, where it has

\footnotetext{
6 Simplistic homophobic arguments against same-sex marriage are common knowledge. They include the arguments that same-sex marriage trivialises heterosexual marriage, degrades the sacredness of marriage, and will encourage a proliferation of gay and lesbian people in society and, if everyone is gay or lesbian, the human race will die out (Warner 1999).

${ }^{7}$ Cf. Friedman (1987), Damsel (1992), Eskridge (1993, 1996), Cox (1994, 2000), Kramer (1997), Culhane (1998), Wedgwood (1999), Hull (2001, 2006), Waaldijk (2001, 2004), Dupuis (2002), Ball (2003), Baird and Rosenbaum (2004), Lannutti (2005), Andersson et al. (2006), Widiss et al. (2007), Gerstmann (2008), Lahey and Alderson (2009), Sullivan (2009), Sherkat et al. (2010), Encarnación (2011), Saez (2011), Spilsbury (2011) and Baunach (2012).

${ }^{8}$ Warner (1999) argues that same-sex marriage has never been broad-based amongst gay and lesbian activists in the US, and depended on the courts for its realisation. A case in point here is that of Baehr vs Lewin, which was ratified by the Hawaii Supreme Court in 1993 and laid the ground for the possibility of gay marriage in the US. Such an appeal was taken up by a small number of lawyers who did not consult with activists or wider groups, and same-sex marriage has subsequently, according to Warner, become a litigation issue.
} 
compellingly argued that its own agenda dovetails with that of the ruling elite". From 1996, the Lesbian and Gay Equality Project (LGEP) ${ }^{9}$ successfully fought to overturn every piece of homophobic legislation, and, as Judge et al. (2008:5) outline, these "legal reforms had passed without much fuss". Their biggest and longest single-issue fight was for same-sex marriage, a battle which lasted from 2002 until 2006 and was the "first LGBTI rights issue to enter the public arena for orchestrated, nation-wide debate" (Judge et al. 2008: 5).

\section{Approaching texts queerly}

Following critical discourse analysis, this article is based on the assumption that the task of language investigations is to ask "questions which are socially critical" (Kamler 1994: 2). The question that I am asking in this article is: Are the same-sex marriage discourses in To Have and to Hold critically investigated? In answering this question, I draw upon a queer theoretical approach to written texts.

Queer theory critiques heteronormativity and all those processes that reinforce what it means to be supposedly "normal": to have a stable identity, to be married to someone of the opposite gender, and to be monogamous. However, queer theorists' critique is not limited to heteronormativity; homonormativity is also under the spotlight. The term "homonormativity" originated in the 1990s in order to describe the side-lining of transgender and bisexual people in the LGBT struggle. In the 2000s, homonormativity is described as being "connected to assimilationist practices and outcomes that mirror heteronormativity" (Motschenbacher and Stegu 2013: 524). In this article, I question the role that same-sex marriage plays in normalising queer desire.

Queer theory is a constantly innovating field that is self-reflexive and will be, according to Butler (1997: 22), "revised, dispelled [and/or] rendered obsolete to the extent that it yields to the demands which resist the term precisely because of the exclusions by which it is mobilized". Ramlow (2009: 131) argues that Butler's insistence on the fluidity of queer is "integral to understanding queering as a methodological tool". Giffney (2009: 7) explains that "queer theory is an exercise in discourse analysis" and the analysis of language, and how it positions difference is therefore central to the queer theory project.

The formal connection between queer theory and language has only emerged over the past couple of years, and queer linguists "analyse language data [...] informed by queer theory" (Motschenbacher and Stegu 2013: 520). More specifically, queer critical discourse analysts "work with a Foucauldian notion of discourse" (Motschenbacher 2011: 166). I approach the same-sex marriage discourse in To Have and to Hold, and specifically the claim by the editors that the text represents a "critical engagement" (Judge et al. 2008: 1) with this discourse, by using Foucault's notion of 'discourse' as being based in complex discursive practices (Foucault 1970, 1972). Foucault's ideas about discourses and sexuality are influential in queer theory, and analysts "seek out the ways in which texts are constructed by interrogating and denaturalising the text's manifold assumptions" (Giffney 2009: 7). For Foucault, discourse is crucial to the production of subjectivity because the link between the individual and the social is through discourse and, therefore, an analysis of the discursive productions can reveal the constructions of identity. Discourse, for Foucault, establishes what is acceptable and unacceptable. This has particular relevance to the same-sex marriage discourses in To Have and to Hold, where

\footnotetext{
${ }^{9}$ In December 1994, the National Coalition for Gay and Lesbian Equality (NCGLE) was formed, initially a coalition of 36 affiliates. In 2002, it was renamed the "Lesbian and Gay Equality Project" (LGEP).
} 
marriage is promoted as acceptable and what deviates from this is viewed as tolerable but ultimately unacceptable.

The common thread that binds the research into same-sex marriage in the South African context (outlined above) is that, although marriage as an institution is problematic or "vexed" (Judge et al. 2008: 8), to deny gay and lesbian people the right to get married is a form of discrimination. Further, to deny gay and lesbian people the "choice" to marry undermines their rights as citizens. Finally, it is argued that gay and lesbian people will "transform" marriage by challenging gender and sexual stereotypes which will undercut homophobic and gender-based discrimination.

What does it entail, then, to think queerly or differently from these points of view on same-sex marriage? To queer representations of same-sex marriage in South Africa means to think differently from the more popular or established views (Milani 2012). It means to destabilise what seems "right" from a liberal viewpoint. In the context of this article, same-sex marriage seems "right" because it ensures that gay and lesbian people have the same access as heterosexual people to the benefits and protections associated with marriage. In a discourse of liberal "rights", to be against same-sex marriage means being aligned with homophobia. However, in this article I oppose homophobia and simultaneously refuse to embrace the "marriage norm as the exclusive or more highly valued social arrangement for queer sexual lives" (Butler 2004: 5). Why would a queer look at same-sex marriage in South Africa be of value if, as Stacey and Meadow (2009: 171) observe, if "one looks at the black letter of the law, South Africa appears to be the most egalitarian society in the world"? Precisely because of the discrepancies between the black letter of liberal laws and the continued prejudice against queer people and people who are "other". Research that provides perspectives that differ from the liberal "rainbow nation" perspective is needed as well as perspectives that ask socially relevant questions that are not confined to the limitations of a human rights discourse.

\section{Analysis of data}

As I mentioned in the introduction to this article, To Have and to Hold is a collection of 40 chapters of which 30 are personal testaments. I have chosen not to analyse the representation of the same-sex marriage discourses in these 20 chapters because of their subjective, emotional and therefore polemic nature. Instead, I focus my analysis on those 10 articles where arguments are made about same-sex marriage and are backed by scholarly evidence. In my analysis of these 10 scholarly articles below, I dissect the logic behind the claims by the various authors that they have critically engaged with those aspects of marriage that are troubling. I further critique those arguments that propose that married gay and lesbian couples will unsettle the normativity associated with marriage. The blurb at the back of To Have and to Hold describes the book as "invaluable for understanding [the same-sex marriage] journey and its legal, social, cultural and religious ramifications". I now put such a claim to the test.

\subsection{Same-sex marriage has "legal ramifications" (choice and benefits)}

The "legal ramifications" argument made by the various contributors to To Have and to Hold in favour of same-sex marriage is aligned with arguments about the "right to choose marriage" and "entitlement to benefits". Judge et al. (2008) acknowledge that marriage is a "conservative, patriarchal, heterosexist convention". However, it is not state legitimation that is the problem 
apropos same-sex marriage for them, but rather the fact that marriage is a "heterosexist convention" that prescribes unequal "sexual and power dynamics" (Judge et al. 2008: 12) . Judge et al. (2008: 12) question whether the struggle for same-sex marriage has "ensured the primacy of heterosexual-style marriage as an institution worth attaining". "Perhaps", they answer, and they admit that same-sex marriage is a "vexed" (Judge et al. 2008: 8) issue because, "rightly or wrongly", marriage carries more symbolic and legal weight in terms of relationships (Judge et al. 2008: 12). However, despite these vexing problems, the editors argue that the struggle for same-sex marriage in South Africa has rather been about "choice" (Judge et al. 2008: 12, original emphasis). This sentiment is unopposed by the various contributors to To Have and to Hold because choice is preferable to not having choice, and choice gives access to benefits.

That in choosing to marry gives access to benefits is made clear by Bilchitz and Judge (2008: 26) who state that "lesbian and gay people demand an equitable share of state resources". Mkhize (2008: 105) adds that gay and lesbian people "deserve equal treatment, protection and regulation by the law as enshrined in the Bill of Rights of our Constitution". Married gay and lesbian couples are able to access state resources and receive equal treatment via the Civil Union Act because the act provides "automatic access to legal protections" (Judge et al. 2008: 12) ${ }^{10}$.

In addition to the legal protections guaranteed by the Civil Union Act, there are "myriad intangible benefits" to same-sex marriage, including the couple's public celebration of their wedding anniversary for the rest of their lives, "while pictures of the day can be displayed in their house and in the houses of their families" (De Vos 2008: 34, original emphasis). I question why these tangible and intangible benefits cannot be made available to single heterosexual and gay and lesbian people or to couples who do not want to marry. This is a question that Bilchitz and Judge as well as Lind attempt to address in their chapters. Bilchitz and Judge (2008: 159) admit that "a large number of South Africans live together in intimate relationships outside of marriage" and Lind (2008: 294) looks forward to family law recognising "queer marriage" which will be an "unmarried relationship recognition". However, the concern about unmarried relationships is addressed by a "wait and see" discourse. Bilchitz and Judge (2008: 160) write that "[c]ontinued activism, public engagement and education will be necessary to ensure that the Act's potential is indeed realized not only in law but in the wider social arena". Lind (2008: 295 ) adds that "an eventual solution to the regulation of unmarried relationships is likely to give us a much clearer idea of how we might successfully promote diversity in the legal recognition of family relationships".

Despite the promise of the Draft Domestic Partners Bill that was tabled in Parliament in 2008 (Department of Home Affairs 2008), and to which Picarra (2007: 569) alludes when she writes that "the possibility may well now exist for unwed heterosexual and same-sex domestic relationships to be brought under the protection of the law", to date no statutes have been passed that recognise single heterosexual and gay and lesbian people, couples who do not want to marry, and diverse families.

\footnotetext{
${ }^{10}$ The 15 benefits conferred by the Civil Union Act are substantial and include the right to inherit, to have children, to adopt children, to choose a marriage contract, to be liable for maintenance, to have marital privilege in civil and criminal law proceedings, and to be subject to the same exchange control regulations and tax exemptions as heterosexuals (Judge et al. 2008: 202).
} 


\subsection{Same-sex marriage has "social ramifications" (love)}

The "social ramifications" argument advanced by the various contributors to To Have and to Hold is aligned with the power of same-sex marriage to transform marriage into "something more radically egalitarian" (Warner 1999: 127). Bilchitz and Judge (2008: 155) argue that same-sex marriage creates "an equal alternative option to marriage [but] also in some sense decentres marriage". The institution of marriage will be decentred because gay and lesbian couples will "do marriage differently [by] redefin[ing] the institution and its prescribed gender roles, hierarchy and inherent financial, sexual and social power dynamics" (Judge et al. 2008: 12). The transformative power of same-sex marriage will be so powerful that an "optimistic forecast is that the realization of sexual liberation will only grow" (Robson 2008: 201).

Prejudice and homophobia will be reduced and might even disappear because same-sex marriage will normalise "homosexuality in our society as an identity" (Reddy and Cakata 2008: 276). Not only will same-sex marriage in South Africa challenge the institution of marriage, encourage sexual liberation and possibly end homophobia, but the Civil Union Act itself will also transform the lives of heterosexual people by "moving family law in the direction of diversity" (Lind 2008: 293). In fact, Bilchitz and Judge (2008: 160) make an even grander claim about the transformative power of this piece of legislation when they write that it is a "giant leap forward for South African family law". Similarly, Lind (2008) argues that, following the Civil Union Act, the next step in the diversification of family law will be the legal recognition of unmarried relationships. He argues that "[1] egal authorities will impute a marriage-like status to relationships that satisfy a large variety of objectively verifiable relationship criteria [because] people who fail to formalize their relationships create difficulties for lawyers and policy makers" (Lind 2008: 293). However, he does concede that trying to legislate the numerous permutations of "unmarried cohabitation is almost impossible" (Lind 2008: 295) ${ }^{11}$.

De Vos presents a similar argument about the transformative and egalitarian nature of the Civil Union Act and its effect on legal reform. The Civil Union Act, he argues, allows both a samesex and a different-sex couple to choose either a marriage or a civil partnership, with identical legal consequences. However, he writes that because of the "special status that marriage has in our society [...] most couples would probably not choose to register 'civil partnerships' if they have the choice of registering a "marriage"" (De Vos 2008: 37-38). One wonders, then, what the purpose of the provision for civil partnerships in the Civil Union Act is when such an inclusion clearly denotes an inferior relationship form.

To summarise, according to the writers above, the Civil Union Act will radically transform not only the patriarchal nature of marriage but will also iron out unequal "sexual and power dynamics" (Judge et al. 2008: 12). The purported transformative power of same-sex marriage in South Africa is thus quite remarkable, and is based on the premise that all gay and lesbian marriages will be characterised by gender, sexual and financial equality, and that they will be inherently less fractious than heterosexual marriage which is clearly unrealistic and utopian.

There is little or no acknowledgement that the Civil Union Act has actually undermined the incremental advances that the state has made with regard to the recognition of gay and lesbian

\footnotetext{
11 The fight for same-sex marriage in South Africa by the LGEP was a well-organised and -strategised legal campaign that showed the power of a progressive alliance between activists and lawyers. No such alliance exists between unmarried people or people in non-standard relationships, and so it is unclear who exactly is going to take up the fight for legal protections for sexualities and practices not based in marriage.
} 
relationships. For example, the Constitutional Court recognised the concept of same-sex relationships in 2000. This recognition was based on the fact that gay and lesbian people could not marry and, in fact, gave gay and lesbian couples more rights than unmarried heterosexual couples. In the case of Gory vs Kolver ${ }^{12}$, the Constitutional Court made it clear that these rights would not automatically be taken away after the passing of the Civil Union Act; gay and lesbian couples could still inherit from one another and jointly adopt children, but not indefinitely. De Vos (2008: 38) makes it clear that

parliament will have the right to amend this kind of legislation in the future to take away the rights of unmarried same-sex couples so that they are treated the same as unmarried heterosexual couples.

This means that those gay and lesbian people who choose not to marry may lose the rights they currently have (to inherit and adopt) because these rights are not granted to unmarried heterosexual people.

The implication of this is that the Civil Union Act, rather than being a transformative and radically egalitarian piece of legislation, actually erodes the validity of unmarried gay and lesbian relationships which may mean that, "in time, same-sex couples who are not married [will] have very little legal protection" (Bilchitz and Judge 2008: 159). Unmarried heterosexual couples are the biggest losers in this "progressive" piece of legislation because, as Bilchitz and Judge (2008: 159) argue, "it is likely" that the courts will still protect those gay and lesbian couples "who have not yet had an opportunity to marry". Therefore, the claim that the Civil Union Act will open a space for the "recognition of diverse sexualities and relationship forms" (Judge et al. 2008: 12) is obviously inaccurate.

\subsection{Same-sex marriage has "cultural and religious ramifications" (respectability)}

The "cultural and religious ramifications" argument put forward by the various contributors to To Have and to Hold associates same-sex marriage with respectability, and is concerned with challenging the association of gay and lesbian people with "sexual subversives" (Kaplan 1997: 204). In fact, the various contributors to To Have and to Hold seem to downplay the importance of sex altogether, and Berger (2008: 21) puts this point of view across clearly when he writes "there's more to a relationship than sex".

From the outset of To Have and to Hold, the editors make it clear that same-sex marriage will "contribute to the 'normalization' of homosexuality" (Judge et al. 2008: 13). In this section, I move away from an analysis of the discursive operations in To Have and to Hold, and concentrate instead on the multimodal signifiers on the front and back cover of the dust jacket. I also include a short analysis of the 32 pages of photographs found in the middle of the book, as they are particularly pertinent to my argument in this section, which is concerned with the supposed respectability that accrues with marriage.

\footnotetext{
${ }^{12}$ Gory vs Kolver led to the Intestate Succession Act 81 of 1987 being declared invalid and unconstitutional since it took into account only the intestate succession of heterosexual spouses (de $\mathrm{Ru} 2009$ ). The consequence of this judgement was that the court granted equal benefits to the surviving partner of a gay relationship in the case of the death of one partner without a will (Judge et al. 2008).
} 


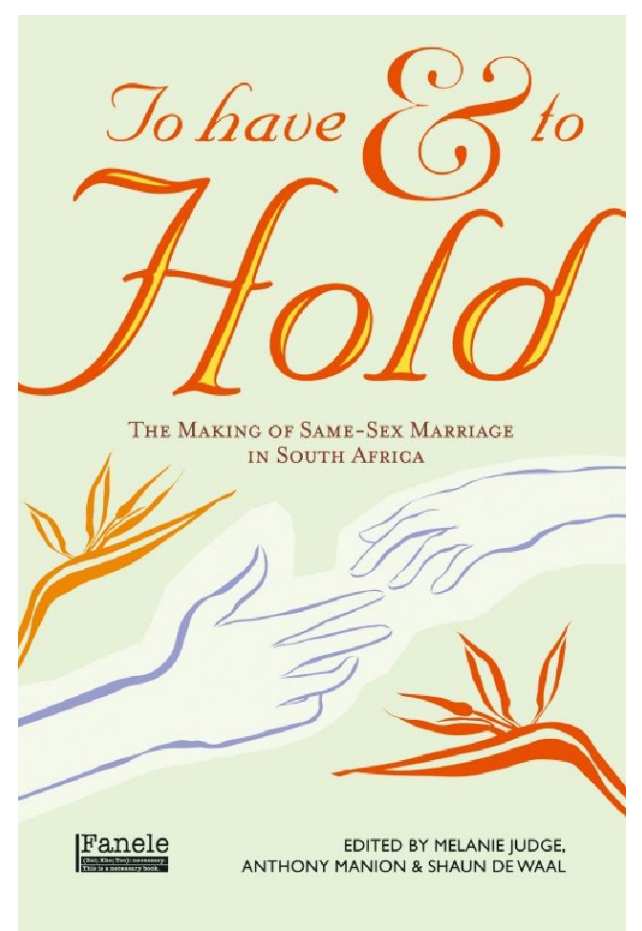

Figure 1. Front cover of To Have and to Hold: The making of same-sex marriage in South Africa (permission granted)

The title To Have and to Hold is a direct quote from a portion of the marriage vows found in the Anglican Book of Common Prayer ${ }^{13}$. The title, therefore, establishes a key theme in the book - the sanctity of marriage - and there is an entire section in the text dedicated to religion and same-sex marriage, albeit from different religious points of view.

The cover of the book is opaque green with the title written in cursive with orange and yellow detail. The size of the ampersand and "Hold" is very large, drawing attention perhaps to the love and comfort associated with marriage. The word "have", which historically connotes a man's right to "have" sex with his wife, has an overt sexual connotation and, possibly as a result, is only one third of the size of the ampersand and "Hold". Beneath the title of the book is the sub-title which is in a much smaller, capitalised, brown font. The sub-title describes the function of the book which is similar to that of a recipe book because it is concerned with "the making of same-sex marriage in South Africa".

Below the sub-title is a graphic of two strelitzias, one on the left-hand side and the other on the right-hand side. The one on the left is smaller than the one on the right and is a lighter shade of orange, while the one on the right is a fiery orange. The strelitzia is also known as the "bird of paradise flower", and symbolises happiness, goodness, freedom and, most importantly, loyalty. The strelitzia is also known as the "crane flower", and cranes are generally known for their monogamy (Newman 2011).

\footnotetext{
13 "I, $N$, take you, $N$, to be my wife (or husband), to have and to hold from this day forward, for better, for worse, for richer, for poorer, in sickness and in health, to love and to cherish, till death us do part, according to God's holy law, and this is my solemn vow" (Cummings 2011: 67).
} 
As I argued in the section above, To Have and to Hold makes many claims about the transformative and egalitarian nature of same-sex marriage, yet it is quite obvious from a reading of the two strelitzias on the cover that they represent the conservative aspects associated with marriage: goodness, happiness and faithfulness. In addition, the fact that the two strelitzias are different sizes and portrayed in different hues of orange clearly indicates "man- and womantype roles" in marriage. In between the two strelitzias is a violet outline of two hands with the index fingers nearly touching; one hand is clearly bigger than the other hand, once again substantiating my claim about the dominant and passive roles in marriage which, it is claimed, same-sex marriage will undo. The image of the two hands clearly draws on "The Creation of Adam" by Michelangelo as a referent, which shows god and Adam's index fingers almost touching. Once again, the religious meaning, solemnity and respectability associated with marriage is reinforced.

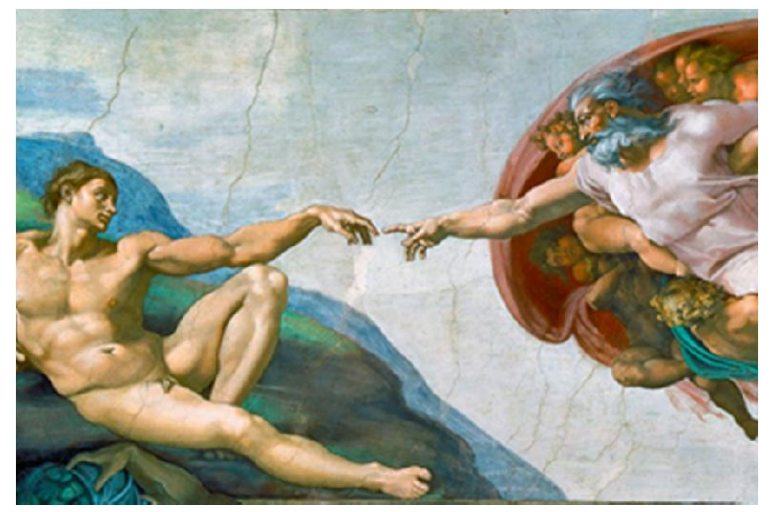

Figure 2. Michaelangelo's “The Creation of Adam” (Cohen 2012)

At the top of the back cover of the book is a substantial quote by Mark Gevisser, a critically acclaimed South African writer. Gevisser's endorsement of To Have and to Hold, which he describes as "eloquent", "persuasive"" and a "must-read", adds credibility not only to the book but also to marriage. Below Gevisser's quote is the blurb, which describes the book as a "milestone" and further positions it as "invaluable for understanding this historic journey and its legal, social, cultural and religious ramifications". The blurb exudes a serious, historic, relevant and revolutionary tone. This tone will appeal to a wide audience, ranging from a curious reader to an activist reader to an academic reader; basically anyone who subscribes to the values of the rainbow nation.

Fifty-seven photographs are published in To Have and to Hold. Of these, 30 photographs are of a diverse array of black and white gay and lesbian couples who have married since the passing of the Civil Union Act in 2006. These couples are neatly attired in a collection of traditional and Western marriage garb. Included in most of the pictures are religious figures (an imam, a rabbi, a priest). The last photo portrays the marriage ceremony of HIV activist Zachie Achmat and his partner Dalli Weyers, with Supreme Court of Appeal Justice Edwin Cameron officiating. These sets of photos depict a very different gay and lesbian community, one that is respectable and "normal"-looking compared to the representations of outlandish drag queens and butch, leather-wearing lesbians published in the press after the annual Pride Parade or Mother City Queer Project. A very neat, clean and sanitised gay and lesbian community occupies the pages of this book. There is not one reference to sex or those sexual and gender 
practices and performances that are often negatively associated with the gay and lesbian subculture but that are an integral part of it (cf. Milani 2013).

\section{Conclusion}

Marriage has been described as a "tool of social control used by governments to regulate sexuality and family formation by establishing a favored form and rewarding it" (Spade and Willse 2013: n.p.). Discriminatory exclusions based on marriage are so intertwined with the power of heteronormativity that one can only question why the progressive gay and lesbian movement in South Africa chose marriage as the primary means of legitimating queer sexual lives. This article tackled this question using a queer analysis of the representation of the samesex marriage discourse in To Have and to Hold. I investigated the claims made by Judge et al. (2008) and the various contributors that the same-sex marriage discourse was critically engaged with, that the passing of the Civil Union Act is historic and, further, that this piece of legislation is moving family law in a progressive direction. In my data analysis section, I have shown that these claims are not true. I have demonstrated how the admission by Judge et al. - that marriage is a conservative, normalising institution that unfairly carries more weight than other forms of relationships - is countered by the argument that the "price of difference in South Africa remains high" (Judge et al. 2008: 13). The liberal "right" discourse is constructed around the possibilities of conservative homophobic discourses becoming a reality. This is opposed by progressive thinkers and writers in To Have and to Hold, even at the expense of "quieting" critical dissension that is not homophobic.

There is no robust engagement with the normativity of marriage or with the fact that, since marriage became enmeshed with the state in the $20^{\text {th }}$ century, it has developed into an institution that is constructed on excluding difference, as embodied in unmarried heterosexual, gay and lesbian people. I also argue that same-sex marriage is only historic for those gay and lesbian people who choose to get married and automatically have access to 15 legal benefits. Finally, given that those few legal protections (such as the right to inherit and adopt) that single and coupled gay and lesbian people had before the passing of the Civil Union Act are likely to be eroded, and that single and unmarried heterosexual people are still without similar protections, I argue that the Civil Union Act is not a progressive step forward for family law in South Africa. Reflecting on the history of the gay and lesbian movement in South Africa in the 1980s and 1990s, when a wide range of political and controversial issues that confronted the gay and lesbian community was on the political and research agendas, one can only ponder how a radical sexual rights movement like the LGEP - which identifies "patriarchy, gender oppression, social conservatism, slavery, colonialism, apartheid and capitalism" (LGEP 2011: n.p.) as the roots of oppression and discrimination in South Africa-came to endorse marriage as the most appropriate way to legitimate queer lives. It has been eight years since the passing of the Civil Union Act, and prejudice, discrimination and violence against gay, lesbian and queer people is rife in South Africa. I would argue that what needs to be engaged with is how homophobia can be opposed without asking the state for legitimation. Butler (2002: 21) argues for the development of nonstate forms of support and alliance between queers, minorities and the abject by revising the "social organization of friendship, sexual contacts, and community". In To Have and to Hold, a particular form of subjectivity is produced around the institution of marriage. On the one hand, marriage is seen as problematic but, on the other hand, the problems associated with marriage are erased in order to produce a coherent account of the power of same-sex marriage to transform all the problematic norms associated with the institution. While it is too soon to assess the impact of 
same-sex marriage on "norms" in South Africa, it is evident that the Civil Union Act actually disadvantages anyone who is not married. Perhaps the time is right in South Africa to start thinking about how we can learn from the many permutations of non-standard family formations (such as child-headed families) and relationship forms that are not based on the myth of monogamous coupling, as these are pervasive but undervalued ways to resist the conservative values associated with marriage.

\section{Acknowledgements}

I would like to thank the University of Johannesburg for their continued support of my queer research. Thanks also to Cathy Burton for editing this manuscript. Finally, I would like to thank the supervisors of my PhD, Carolyn McKinney and Ann Smith, for their insights into the chapter of my thesis that eventually became this article.

\section{References}

Andersson, G., T. Noack, A. Seierstad and H. Weedon-Fekjær. 2006. The demographics of same-sex marriages in Norway and Sweden. Demography 43(1): 79-98.

Baird, R.M. and S.E. Rosenbaum (Eds.) 2004. Same-sex marriage: The moral and legal debate. New York: Prometheus Books.

Ball, C.A. 2003. Positive in the fundamental right to marry: Same-sex marriage in the aftermath of Lawrence v. Texas. Minnesota Law Review 88: 1184.

Barnard, J. 2007. Totalitarianism, (same-sex) marriage and democratic politics in postapartheid South Africa. South African Journal on Human Rights: Sexuality and the Law: Special Issue 23(3): 500-525.

Baunach, D.M. 2012. Changing same-sex marriage attitudes in America from 1988 through 2010. Public Opinion Quarterly 76(2): 364-378.

Berger, J. 2008. Getting to the Constitutional Court on time: A litigation history of same-sex marriage. In M. Judge, A. Manion and S. de Waal (Eds.) To have and to hold: The making of same-sex marriage in South Africa. Fanele: Auckland Park. pp. 17-28.

Bilchitz, D. and M. Judge. 2007. For whom does the bell toll? The challenges and possibilities of the Civil Union Act for family law in South Africa. South African Journal on Human Rights: Sexuality and the Law: Special Issue 23(3): 466-499.

Bilchitz, D. and M. Judge. 2008. The Civil Union Act: Messy compromise or giant leap forward? In M. Judge, A. Manion and S. de Waal (Eds.) To have and to hold: The making of same-sex marriage in South Africa. Auckland Park: Fanele. pp. 149-163.

Bonthuys, E. 2008a. Possibilities foreclosed: The Civil Union Act and lesbian and gay identity in South Africa. Sexualities 11(6): 726-739. 
Bonthuys, E. 2008b. The Civil Union Act: More of the same. In M. Judge, A. Manion and S. de Waal (Eds.) To have and to hold: The making of same-sex marriage in South Africa. Fanele: Auckland Park. pp. 171-181.

Brandzel, A.L. 2005. Queering citizenship? Same-sex marriage and the state. GLQ: A Journal of Lesbian and Gay Studies 11(2): 171-204.

Butler, J. 1990. Gender trouble: Feminism and the subversion of identity. New York: Routledge.

Butler, J. 1997. Critically queer. In S. Phelan (Ed.) Playing with fire: Queer politics, queer theories. New York: Routledge. pp. 11-30.

Butler, J. 2002. Is kinship always already heterosexual? Differences: A Journal of Feminist Cultural Studies 13(1): 14-44.

Butler, J. 2004. Undoing gender. New York: Routledge.

Cock, J. 2003. Engendering gay and lesbian rights: The equality clause in the South African Constitution. Women's Studies International Forum 26(1): 35-45.

Cohen, J. 2012. 7 things you may not know about the Sistine Chapel. Available online: http://www.history.com/news/7-things-you-may-not-know-about-the-sistine-chapel (Accessed 26 February 2015).

Cox, B.J. 1994. Same-sex marriage and choice-of-law: If we marry in Hawaii, are we still married when we return home? Wisconsin Law Review: 1033-1118.

Cox, B.J. 2000. But why not marriage: An essay on Vermont's Civil Unions Law, same-sex marriage, and separate but (un)equal. Vermont Law Review 25: 113-147.

Culhane, J.G. 1998. Uprooting the arguments against same-sex marriage. Cardozo Law Review 20: 1119-1211.

Cummings, B. (Ed.) 2011. The book of common prayer: The texts of 1549, 1559, and 1662. Oxford: Oxford University Press.

Damsel, O.R. 1992. Same-sex marriage. New York Law School Journal of Human Rights 10(2): 555-595.

De Ru, H. 2009. The Recognition of Same-Sex Unions in South Africa. Unpublished Master's thesis, University of South Africa.

De Vos, P. 2007. The 'inevitability' of same-sex marriage in South Africa's post-apartheid state. South African Journal on Human Rights: Sexuality and the Law: Special Issue 23(3): 432-465. 
De Vos, P. 2008. Difference and belonging: The Constitutional Court and the adoption of the Civil Union Act. In M. Judge, A. Manion and S. de Waal (Eds.) To have and to hold: The making of same-sex marriage in South Africa. Auckland Park: Fanele. pp. 29-41.

De Vos, P. and J. Barnard. 2007. Same-sex marriage, civil unions and domestic partnerships in South Africa: Critical reflections on an ongoing saga. South African Law Journal 124(4): 795 826.

Department of Home Affairs, South Africa. 2008. Notice 36 of 2008: Department of Home Affairs Domestic Partnership Bill, 2008: Publication of the Draft Domestic Partnerships Bill, 2008 for comments. Government Gazette No. 30663, 14 January 2008. Available online: http://www.gov.za/sites/www.gov.za/files/30663b.pdf (Accessed 26 August 2015).

Dupuis, M. 2002. Same-sex marriage, legal mobilization, and the politics of rights. New York: Peter Lang.

Dworkin, R. 2006. Three questions for America. New York: New York Review of Books.

Encarnación, O.G. 2011. Latin America's gay rights revolution. Journal of Democracy 22(2): 104-118.

Eskridge Jr., W.N. 1993. A history of same-sex marriage. Virginia Law Review 79: 1419-1513.

Eskridge Jr., W.N. 1996. Case for same-sex marriage: From sexual liberty to civilized commitment. New York: Free Press.

Ettelbrick, P. 1997. Since when is marriage a path to liberation? OUT/LOOK: National Lesbian \& Gay Quarterly 6: 14-16.

Foucault, M. 1970. The order of things: An archaeology of the human sciences. (Translated by A.M. Sheridan Smith.) New York: Pantheon Books.

Foucault, M. 1972. The archaeology of knowledge and the discourse on language. (Translated by A.M. Sheridan Smith.) New York: Pantheon Books.

Friedman, A. 1987. The necessity for state recognition of same-sex marriage: Constitutional requirements and evolving notions of family. The Berkeley Women's Law Journal 3: 134.

Gerstmann, E. 2008. Same-sex marriage and the Constitution. Cambridge: Cambridge University Press.

Giffney, N. 2009. Introduction: The 'q' word. In N. Giffney and M. O'Rourke (Eds.) The Ashgate research companion to queer theory. Burlington: Ashgate Publishing Limited. pp. 1-13.

Goldblatt, B. 2006. Case note: Same-sex marriage in South Africa - The Constitutional Court's judgement. Feminist Legal Studies 14: 261-270. 
Goldblatt, B. and A. Pantazis. 2007. Introduction-focus on sexuality and the law. South African Journal on Human Rights: Sexuality and the Law: Special Issue 23(3): 407-408.

Halberstam, J.J. 2012. Gaga feminism: Sex, gender, and the end of normal. Boston: Beacon Press.

Hames, M. 2008. Lesbians and the Civil Union Act in South Africa: A critical reflection. In M. Judge, A. Manion and S. de Waal (Eds.) To have and to hold: The making of same-sex marriage in South Africa. Auckland Park: Fanele. pp. 258-267.

Hull, K.E. 2001. The political limits of the rights frame: The case of same-sex marriage in Hawaii. Sociological Perspectives 44(2): 207-232.

Hull, K.E. 2006. Same-sex marriage: The cultural politics of love and law. Cambridge: Cambridge University Press.

Judge, M. 2014. For better or worse? Same-sex marriage and the (re)making of hegemonic masculinities and femininities in South Africa. Agenda: Empowering Women for Gender Equity 28(2): 67-73.

Judge, M., A. Manion and S. de Waal (Eds.) 2008. To have and to hold: The making of samesex marriage in South Africa. Auckland Park: Fanele.

Judge, M., A. Manion and S. de Waal. 2008. Introduction. In M. Judge, A. Manion and S. de Waal (Eds.) To have and to hold: The making of same-sex marriage in South Africa. Auckland Park: Fanele. pp. 1-16.

Kamler, B. 1994. Lessons about language and gender. Australian Journal of Language and Literacy 17(2): 129-138.

Kaplan, M.B. 1997. Intimacy and equality: The question of lesbian and gay marriage. In S. Phelan (Ed.) Playing with fire: Queer politics, queer theories. New York: Routledge. pp. 201-230.

Kramer, L. 1997. Same-sex marriage, conflict of laws, and the unconstitutional public policy exception. Yale Law Journal 106(7): 1965-2008.

Lahey, K.A. and K. Alderson. 2009. Same-sex marriage. New York: Insomniac Press.

Lannutti, P.J. 2005. For better or worse: Exploring the meanings of same-sex marriage within the lesbian, gay, bisexual and transgendered community. Journal of Social and Personal Relationships 22(1): 5-18.

The Lesbian and Gay Equality Project (LGEB). 2011. Available online: http://www.equality.org.za (Accessed 28 September 2011).

Lind, C. 2008. Queering marriage? The legal recognition of same-sex relationships around the world. In M. Judge, A. Manion and S. de Waal (Eds.) To have and to hold: The making of samesex marriage in South Africa. Auckland Park: Fanele. pp. 284-299. 
Milani, T.M. 2012. Queering the matrix? Discursive regimes of language and identity in HIV/AIDS contexts. SPiL Plus 4: 59-75.

Milani, T.M. 2013. Are 'queers' really 'queer'? Language, identity and same-sex desire in a South African online community. Discourse \& Society 24(5): 615-633.

Mkhize, N. 2008. (Not) in my culture: Thoughts on same-sex marriage and African practices. In M. Judge, A. Manion and S. de Waal (Eds.) To have and to hold: The making of same-sex marriage in South Africa. Auckland Park: Fanele. pp. 97-106.

Motschenbacher, H. 2011. Taking Queer Linguistics further: Sociolinguistics and critical heteronormativity research. International Journal of the Sociology of Language 212: 149-179.

Motschenbacher, H. and M. Stegu. 2013. Queer linguistic approaches to discourse. Discourse \& Society 24(5): 519-535.

Newman, K. 2011. Newman's birds of Southern Africa. Johannesburg: Random House.

Oswin, N. 2007. Producing homonormativity in neoliberal South Africa: Recognition, redistribution, and the equality project. Signs 32(3): 649-669.

Picarra, L. 2007. Gory v Kolver No 2007 (4) SA 97 (CC): Notes and comments. South African Journal on Human Rights: Sexuality and the Law: Special Issue 23(3): 563-569.

Polikoff, A.N.D. 2008. Beyond straight and gay marriage: Valuing all families under the law. Boston: Beacon Press.

Ramlow, T.R. 2009. Queering, cripping. In N. Giffney and M. O'Rourke (Eds.) The Ashgate research companion to queer theory. Burlington: Ashgate Publishing Limited. pp. 129-146.

Reddy, V. 2006. Decriminalisation of homosexuality in post-apartheid South Africa: A brief legal case history review from sodomy to marriage. Agenda: Empowering Women for Gender Equity 20(67): 146-157.

Reddy, V. 2009. Queer marriage: Sexualising citizenship and the development of freedoms in South Africa. In M. Steyn and M. Van Zyl (Eds.) The prize and the price: Shaping sexualities in South Africa. Cape Town: HSRC Press. pp. 241-363.

Reddy V. and Z. Cakata. 2008. Marriage, citizenship and contested meanings. In M. Judge, A. Manion and S. de Waal (Eds.) To have and to hold: The making of same-sex marriage in South Africa. Auckland Park: Fanele. pp. 274-277.

Robinson, J.A. and J. Swanepoel. 2004. Same-sex marriage in South Africa: The road ahead. Potchefstroom Electronic Law Journal 7(1): 1-21.

Robson, R. 2007. Sexual democracy. South African Journal on Human Rights: Sexuality and the Law: Special Issue 23(3): 409-431. 
Robson, R. 2008. On rupture and rhyme: Perspectives on the past, present, and future of samesex marriage. In M. Judge, A. Manion and S. de Waal (Eds.) To have and to hold: The making of same-sex marriage in South Africa. Auckland Park: Fanele. pp. 193-201.

Saalfield, C. 1993. Lesbian marriage ... (k)not! In A. Stein (Ed.) Sisters, sexperts, queers: Beyond the lesbian nation. New York: Penguin. pp. 187-195.

Saez, M. 2011. Same-sex marriage, same-sex cohabitation, and same-sex families around the world: Why 'same' is so different? American University Journal of Gender Social Policy \& Law 19(1): 1-54.

Sherkat, D.E., K.M. de Vries and S. Creek. 2010. Race, religion, and opposition to same-sex marriage. Social Science Quarterly 91(1): 80-98.

Spade, D. and C. Willse. 2013. Marriage will never set us free. Available online: http://www.organizingupgrade.com/index.php/modules-menu/beyond-capitalism/item/1002marriage-will-never-set-us-free (Accessed 10 September 2013).

Spilsbury, L. 2011. Same-sex marriage. New York: The Rosen Publishing Group.

Stacey, J. and T. Meadow. 2009. New slants on the slippery slope: The politics of polygamy and gay family rights in South Africa and the United States. Politics \& Society 37(2): 167-202.

Sullivan, A. 2009. Same-sex marriage: Pro and con. New York: Vintage.

Thoreson, R.R. 2008. Somewhere over the Rainbow Nation: Gay, lesbian and bisexual activism in South Africa. Journal of Southern African Studies 34(3): 679-697.

Van Zyl, M. 2011. Are same-sex marriages unAfrican? Same-sex relationships and belonging in post-apartheid South Africa. Journal of Social Issues 67(2): 335-357.

Vasquez, C. 1999. Citizen queer. In K. Kleindienst (Ed.) This is what a lesbian looks like: Dyke activists take on the 21st century. Ithaca, NY: Firebrand Books. pp. 268-283.

Waaldijk, C. 2001. Small change: How the road to same-sex marriage got paved in the Netherlands. Available online: https://openaccess.leidenuniv.n1/handle/1887/3609 (Accessed 13 March 2015).

Waaldijk, K. 2004. Others may follow: The introduction of marriage, quasi-marriage, and semimarriage for same-sex couples in European countries. Judicial Studies Institute Journal 5(1): 104-127.

Walters, S.D. 2001. 'Take my domestic partner, please': Gays and marriage in the era of the visible. In M. Bernstein and R. Reimann (Eds.) Queer families, queer politics: Challenging culture and the state. New York: Columbia University Press. pp. 338-357.

Warner, M. 1999. The trouble with normal: Sex, politics, and the ethics of queer life. Cambridge: Harvard University Press. 
Wedgwood, R. 1999. The fundamental argument for same-sex marriage. Journal of Political Philosophy 7(3): 225-242.

Widiss, D.A., E.L. Rosenblatt and D. NeJaime. 2007. Exposing sex stereotypes in recent samesex marriage jurisprudence. Harvard Journal of Law and Gender 30: 461-505.

Williams, K. 2004. I do or 'we won't': Legalising same-sex marriage in South Africa. South African Journal on Human Rights 20(1): 32-63.

Willse, C. and D. Spade. 2005. Freedom in a regulatory state?: Lawrence, marriage and biopolitics. Widener Law Review 11: 309-330.

Yarbrough, M.W. 2006. South Africa's wedding jitters: Consolidation, abolition or proliferation. Yale Journal of Law and Feminism 18(2): 497-521.

Yep, G.A., K.E. Lovaas and J.P. Elia. 2003. A critical appraisal of assimilationist and radical ideologies underlying same-sex marriage in LGBT communities in the United States. Journal of Homosexuality 45(1): 45-64. 